\title{
JUURNAL.RU
}

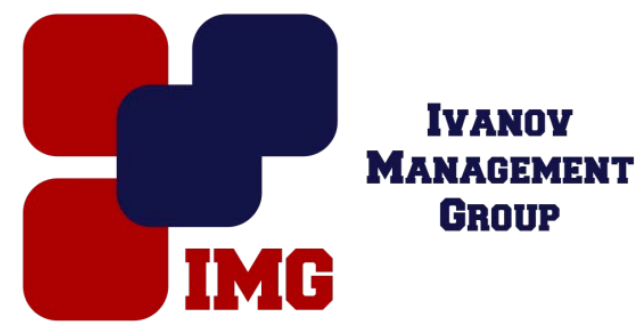

Сергеева А.И. Тверской государственный технический университет Тверь, Россия

doi: 10.18411/lj-30-11-2016-4-10

idsp 000001:lj-30-11-2016-4-10

\section{Обоснование необходимости проведение реструктуризации предприятий}

\section{Аннотация}

В статье обоснована необходимость проведения реструктуризации предприятий. Рассмотрены различные подходы к классификациям целей и предпосылок для внедрения преобразований, а также некоторые особенности понимания реструктурирования в России и за ее пределами.

Ключевые слова: реструктуризация, цели, предпосылки, необходимость.

Для зарубежных предприятий процесс реструктурирования стал неотъемлемой частью их жизнедеятельности. Это означает естественный, постоянный процесс перестройки и перепроектирования для адаптации $\mathrm{\kappa}$ изменчивой внешней среде. В российской практике особенность проведения реструктуризации проявляется в ее необходимости, а именно при возникновении потребности организации в кардинальных изменениях и не является частью повседневного делового цикла предприятия. Она требует специального планирования, значительной предварительной подготовки, в том числе и исследовательской работы, и многого другого. Это, своего рода стратегия, которая призвана решить ряд задач на пути к определенной цели. Такими целями могут быть как выведение предприятия из кризиса, так и повышение конкурентоспособности, достижение стабильного положения на рынке.

Реструктуризация - процесс сугубо внутрифирменный. В этом, по мнению О. Алехиной главное отличие ее от развития нового бизнеса, для которого принято привлекать средства внешних инвесторов. В данном случае адаптируясь к среде, предприятие меняет и методы своего функционирования, в частности способы принятия решений. Предприятие - это система. Независимо от того, какой системный «срез» рассматривается, его преобразование означает реструктуризацию. Но стоит отметить, что анализ внешней и внутренней среды может выявить серьезный конфликт между этими составляющими, для 
разрешения которого будет недостаточно трансформации действующей структуры. В данном случае необходим другой подход к ведению бизнеса.

Сама по себе реструктуризация не является необходимостью в статичном состоянии окружающей среды, так как несет в себе адаптивную функцию, которая реализует себя, сталкиваясь с какими-либо отклонениями либо предвидя их. Именно поэтому хотелось бы отметить ключевое, в данном случае, понятие «изменение». Изменение - это превращение в нечто другое, перемена состояния объекта путем привнесения новых черт в его структуру. Исходя из этого подхода, можно выделить предпосылки для проведения реструктуризации предприятия.

Большинство авторов называют три основных (укрупненных) фактора, служащих отправной базой для проведения реструктуризации:

- условия внешней среды;

- внутреннее состояние предприятия;

- формирование или изменение стратегии предприятия.

М.C. Мотышина отмечает еще одну предпосылку реструктуризации отечественных предприятий: изменения условий хозяйствования.

К таким изменениям, наряду с глобальными переменами на внешних рынках (как зарубежных, так и национальном), формированием новых условий для бизнеса (в частности связанных с внедрением новых технологий), на наш взгляд, необходимо отметить отраслевые структурные изменения, в том числе интеграцию деятельности предприятий, слияние и поглощение.

В.А. Баринов предлагает рассмотреть следующие причины возникновения потребности в структурном преобразовании:

1) Вывод компании из кризиса;

2) Реструктуризация компании как комплекс мер по его обновлению и повышению конкурентоспособности;

3) Разукрупнение компании для повышения управляемости и экономической эффективности;

4) Перепроектирование компании на принципах определения состояния «как должно быть».

Первые две предпосылки очевидны и не нуждаются в повышенном внимании. Интерес представляют третий и четвертый пункты классификации. Их разница заключается в уровне развития менеджмента. Правильное видение того «как должно быть» и стремление к определенной модели не имеют места без профессионального подхода к управлению. Не зря одним из ресурсов для создания бизнеса является наличие предпринимательских способностей. Разукрупнение, то есть создание дочерних обществ, свойственно незрелому менеджменту. Хотя усиление контроля, повышение управляемости и сокращение объема выполняемой оперативной работы, играют немаловажную роль и для опытных руководителей.

Приведем классификацию целей реализации стратегии реструктуризации О.В. Ленковой. 
Во-первых, выход из кризиса и предотвращение кризисной ситуации (в широком понимании конфликт предприятия с внешней средой).

Во-вторых, обеспечение необходимых условий для достижения оптимального соотношения между прибыльностью и стабильностью.

В-третьих, полное использование потенциала роста предприятия и, вчетвертых, увеличение стоимости бизнеса.

В современной научной литературе существует множество вариантов трактовки понятия «реструктуризация». Это связано с тем, что юридически такое понятие не закреплено (используется лишь термин «реорганизация»). Из данных определений можно выявить основные цели, которые, по мнению авторов, призвана решить реструктуризация. Рассмотрим такие цели и задачи в Таблице 1.

Таблица 1.

Основные цеели и задачи проведения реструктуризации, исходя из подходов к определению данного термина

\begin{tabular}{|c|c|}
\hline Цель, задачи & Автор \\
\hline Улучшение управления & $\begin{array}{c}\text { Министерство экономики РФ, Захаров М.В., Карлик } \\
\text { А., Гришпун Е. }\end{array}$ \\
\hline $\begin{array}{c}\text { Эффективное использование всех ресурсов } \\
\text { предприятия и увеличение доходности }\end{array}$ & $\begin{array}{c}\text { Дж. Монтгомери, Яковлева В.А., Крыжановский } \\
\text { В.Г., Минаев Э.С., Панагушин В.П., Горбачев В.Л., } \\
\text { Баринов В.А., Яковлева В.А. }\end{array}$ \\
\hline $\begin{array}{c}\text { Улучшение финансово-экономических результатов } \\
\text { деятельности, повышение конкурентоспособности и } \\
\text { инвестиционной привлекательности, развитие } \\
\text { предприятия }\end{array}$ & $\begin{array}{c}\text { Министерство экономики РФ, Яковлева В.А., Мазур } \\
\text { И.И., Шапиро В.Д., Тутунджян А.К., Противень Р.Б., } \\
\text { Мерзликина Г.С., Семикин Е.А., Валдайцев С.В., } \\
\text { Анистов М.Д., Бляхман Л.С. }\end{array}$ \\
\hline $\begin{array}{c}\text { Финансовое оздоровление, устойчивость, выход из } \\
\text { кризиса }\end{array}$ & $\begin{array}{c}\text { Коноков Д., Рожков К., Евсеев А., Синягин А., } \\
\text { Противень Р.Б., Белых Л. П., Федотова М.А., } \\
\text { Евтушенко Е.В. }\end{array}$ \\
\hline
\end{tabular}

Интересный вариант определения цели проведения реструктуризации выдвинул Коротков Э.М.: «Изменение структуры по определенным параметрам... в связи с изменившимися условиями и в целях позитивного решения проблемы».

Таким образом, проведенное исследование показало, что большинство источников предоставляют достаточно однородную информацию в области классификаций предпосылок для проведения реструктуризации. Данный процесс следует рассматривать как естественный, перманентный, так, как это принято в международном понимании. Во время мониторинга системы, во многих случаях руководство сталкивается со снижением эффективности своей деятельности. Здесь, реакцией при получении такого рода результата должна служить разработка мер по устранению недостатков структуры. В этом и заключается смысл проведения преобразований. 


\section{Литература}

1. С.В. Хайниш, Менеджмент и бизнес в слабоструктурированном мире - М : Едиториал УРСС, 2013 г. - стр. 87-93;

2. В. Я. Захаров, А.О. Блинов, Д.В. Хавин, Антикризисное управление. Теория и практика - М.: ЮНИТИ-ДАНА, 2006 г. - стр. 150-152;

3. М.С. Мотышина, Социально-экономические организации. Концепции, особенности, механизмы развития - СПбГУП, 2009 г. - стр. 176-191;

4. В.А. Баринов, Организационное проектирование - М. : ИНФРА - М, 2012г. - стр. 284-286;

5. О.В. Ленкова, Механизм формирования стратегии реструктуризации предприятия// Экономика и предпринимательство - 2014 г., №8 - стр. 443446;

6. О. Воробьева, Современная трактовка понятия «реструктуризация»// Проблемы теории и практики управления - 2010 г., №10 - стр. 117-123. 